\title{
Relationship Between Intrinsic/Extrinsic Motivation and L2 Speaking Skill Among Iranian Male and Female EFL Learners
}

\author{
La relación entre la motivación intrínseca/extrínseca y la habilidad \\ de hablar inglés L2 entre los estudiantes masculinos y femeninos \\ iranies de EFL
}

\author{
Gholamreza Salehpour \\ Ali Roohani \\ Shabrekord University
}

\begin{abstract}
This study investigated the relationship between intrinsic/extrinsic motivation and L2 (English) speaking skill between male and female high school students in Iranian EFL context. To this end, 249 male and female students' intrinsic and extrinsic motivation was measured with a questionnaire and their English speaking skill was assessed by a speaking rating scale. To triangulate the data, semistructured interviews with a sample of $25 \mathrm{EFL}$ students were conducted. The results of descriptive statistics and correlation coefficients demonstrated that the females had a higher level of intrinsic motivation while the males had a higher level of extrinsic motivation. Besides, the degree of correlation between intrinsic motivation and attainment of L2 speaking skill was statistically higher among the females. Also, t-test results indicated a statistically significant difference in the intrinsic/extrinsic type of motivation between the male and female students. The findings highlight the role of gender in dealing with motivation in L2 classes.
\end{abstract}

Keywords: Extrinsic/intrinsic motivation; Gender; Speaking skill

\section{Resumen}

En este estudio se ha investigado la relación entre la motivación extrínseca/intrínseca y la habilidad de hablar inglés L2 entre estudiantes de secundaria masculinos y femeninos en el contexto de EFL de Irán. La motivación intrínseca y extrínseca de 249 estudiantes masculinos y femeninos se midió con un cuestionario y su habilidad para hablar inglés se evaluó con una escala de calificación oral. Para triangular los datos, se realizaron entrevistas semiestructuradas con una muestra de 25 estudiantes de EFL. Los resultados de estadística descriptiva y los coeficientes de correlación demostraron que las mujeres tenían un mayor nivel de motivación intrínseca, mientras que los hombres tenían un mayor nivel de motivación extrínseca. Además, el grado de correlación entre la motivación intrínseca y el logro de la habilidad de hablar L2 fue estadísticamente mayor entre las mujeres. Los resultados de la prueba$\mathrm{t}$ indicaron también una diferencia estadísticamente significativa en la motivación intrínseca/extrínseca entre los estudiantes masculinos y femeninos. Los resultados destacan el papel del género en el tratamiento de la motivación en las clases de L2.

Palabras clave: Motivación intrínseca/extrínseca; Género; Habilidad de hablar 


\section{INTRODUCTION}

Affective variables are regarded as one of the most important individual variables (Brown, 2014). One of these affective variables is motivation, which refers to the desire to initiate L2 learning and the effort employed to sustain it (Ortega, 2009). Motivation for L2 learning is a multifaceted construct, the two dimensions of which are intrinsic and extrinsic motivation. Intrinsic motivation is defined as "the inherent tendency to seek out novelty and challenges, to extend and exercise one's capacities, to explore, and to learn” (Ryan \& Deci, 2000, p. 70). Intrinsic motivation is an essential type of motivation. However, most of the actions taken by most people are not intrinsically motivated. On the other hand, the term extrinsic motivation "involves doing an activity to attain a separable consequence, whether tangible or otherwise" (Deci, Olafsen, \& Ryan, 2017, p. 21). In fact, extrinsic motivation implies instrumental or external behaviors.

Ignoring motivation is like removing a catalyst for optimal learning. Also, based on L2 research findings (e.g. Dörnyei, 2005; Noels, Pelletier, Clément, \& Vallerand, 2000) motivation is an important individual learner variable in L2 learning. It "serves as the initial engine to generate learning and later functions as a driving force that helps to sustain the long journey of acquiring a foreign language" (Cheng \& Dörnyei, 2007, p. 153). Dörnyei (2010, p. 74) believes that "learners with sufficient motivation can achieve a working knowledge of an L2, regardless of their language aptitude, whereas without sufficient motivation even the brightest learners are unlikely to persist long enough to attain any really useful language." Also, as noted by Ehrman, Leaver, and Oxford (2003), some researchers have contended that intrinsic motivation correlates more closely with language learning success than extrinsic motivation. However, it is not quite clear which one is more related to higher levels of achievements in L2 oral skills.

Furthermore, several studies (e.g. Polat, 2007) indicate that females are better language learners. However, research findings cannot definitely support the female superiority in L2 learning (Ehrlich, 1997). Thus, several L2 researchers (e.g. Baker \& MacIntyre, 2000; Kang, 2000) have called for investigation into gender differences in motivation and L2 learning. However, the interaction of gender and motivation has not been sufficiently studied (Dörnyei, 2003). In particular, a paucity of research is felt with regard to the interaction of EFL (English as a foreign language) learners' gender with their motivation in L2 learning, including L2 speaking skill, in Iran. 
Thus, this study aimed to investigate intrinsic and extrinsic motivation, which may differently help male and female EFL learners attain language skills. More specifically, it sought to examine the relationship between intrinsic and extrinsic type of motivation and attainment of L2 (English) speaking skill among male and female high school EFL students. That is to say, differences in the degrees and forms of motivation among some Iranian high school EFL students were investigated to see how these differences could affect developing speaking skills in English. In this light, the present study can shed light on the interaction of gender, motivation and development of L2 speaking skill. The results bear significance as they can help L2 teachers in their pedagogical practices to recruit appropriate types of motivation in their male and female L2 learners. This is important because as Baker and MacIntyre (2000) suggest, instructional practices can be influenced by gender differences in motivation for L2 learning.

\section{LITERATURE REVIEW}

\section{Motivation}

Motivation can be considered from behavioristic, cognitive and constructivist perspectives (Brown, 2014). According to Brown (2014), behaviorists regard motivation, which is affected by external and internal forces, as the anticipation of or desire for rewards and positive reinforcement. Cognitivists perceive motivation as driven by basic human needs. According to cognitivists, motivation is affected by internal and individual forces. Constructivists believe that motivation is socially constructed and it is affected by such factors as social context, internal and interactive forces, community, and social status. Brown (2014) tried to integrate the three aforementioned perspectives and give a more comprehensive definition. According to him, motivation is a needs concept whereby "the fulfillment of needs is rewarding, requires choices, and in many cases must be interpreted in a social context" (p. 169).

In relating motivation to language achievement, several theoretical models and definitions have been presented. Gardner and his associates described the construct in his Attitude Motivation Index (AMI), and talked about three aspects of motivation: effort, the desire to achieve a goal, and attitude (Gardner, 1985). The bipolar concept of orientation to language learning in this index is integrative versus instrumental motivation. The integrative type of motivation includes the desire to interact with or gain knowledge about the speakers of the target language (TL). 
On the other hand, instrumental motivation values practical goals like career, educational, or financial goals (Brown, 2014). Research findings indicate support for the association between integrative motivation and L2 achievement (e.g., Gardner, Tremblay, \& Masgoret, 1997; Kang, 2000; Khorshidi \& Nimchahi, 2013). Some other studies have linked instrumental motivation to L2 achievement (e.g. Dörnyei, 2005). However, Saville-Troike (2006) states that neither of the two constructs has an inherent advantage over the other in L2 achievement. It can be fairly posited that both types of motivation are associated with language learning to a certain extent (Dörnyei \& Ushioda, 2011).

A further definition assumes that motivation is a dynamic, continually evolving concept which consists of two aspects: Intrinsic and extrinsic motivation (Deci, 1975; Dörnyei, 1998). An example of intrinsic motivation is engaging in behaviors with the purpose of experiencing joy and/or satisfaction (Dörnyei, 1998). People who are intrinsically motivated seem to "engage in activities for their own sake" rather than for rewards which are external to an activity (Deci, 1975, p. 23). On the other hand, extrinsic motivation is associated with the anticipation of extrinsic rewards or avoidance of punishment (Dörnyei, 1998). Therefore, learners are motivated primarily intrinsically or extrinsically based on how they are affected by internal or external influences.

Also, regarding the relationship between L2 achievement and motivation, there are some findings indicting the relationships between intrinsic motivation and achievements in language learning (e.g. Brown, 2014; Logan, Medford, \& Hughes, 2011). Some have reported a positive correlation between intrinsic motivation and language attainment and a negative correlation between extrinsic motivation and language attainment (e.g. Busse, 2013). Some researchers (e.g. Logan et al., 2011; Noels, Clément, \& Pelletier, 2001) found that intrinsic motivation rather than extrinsic motivation is correlated with language achievement. Research also has demonstrated that intrinsic motivation is a significant factor influencing learners' interactional behaviors (Xie \& Ke, 2011). Further research (e.g. Paige, 2011; Wang, 2008) has showed that extrinsic motivation can serve to develop intrinsic motivation and language achievement. However, some research (e.g., Geddes, 2016 ) is indicative of the equal importance of the two motivational constructs for language attainment. In sum, intrinsic and extrinsic motivations are considered as one of the most powerful dimensions of the motivation construct. Therefore, it is worth investigating this kind of motivation in relation to L2 learners' speaking skills. 


\section{Gender and Motivation}

Gender is another individual variable that may affect L2 learning. In relating gender to success in L2 learning, current research in L2 learning perceives gender as a less generalizable phenomenon that is socially constructed (Norton \& Toohey, 2004). Some evidence about how gender differences relate to L2 learning is provided by research (see Norton \& Pavlenko, 2004), and several L2 theories (see Schumann, 1976) pay attention to the issue of gender differences.

Although research in this area is somewhat limited, it has been reported that men and women have different motivation orientations towards language learning. Some studies suggest that women are more motivated than men in L2 attainment (Baker \& MacIntyre, 2000). For example, in the research conducted by Kang (2000), females consistently reported higher integrative motivational orientation than males. Williams, Burden, and Lanvers (2002) found that British males were significantly less motivated than females in learning French and German. Kissau (2006) found that Canadian females consistently made more effort than males to learn and use French. Higher motivation among women was reported by Fukuchi (2005), who used self-reported motivation measurements for the students studying English in Japan. However, Jegede (1994) found that gender differences did not predict motivation for achievement among Nigerian secondary school students learning English.

Furthermore, some researchers (e.g. Narayanan, Nair, \& Iyyappan, 2007) have studied gender differences in terms of motivation type. Results indicate that women have higher overall motivation rather than distinct forms of motivation. For example, Narayanan, et al. (2007) explored the motivation of college English language learners and reported that females displayed higher ratings of all four types of motivation: integrative, instrumental, resultative, and intrinsic. Semmar's (2006) findings also indicated that females had higher ratings for both extrinsic and intrinsic orientations as well as for motivational strength. Goldberg and Wolfe (1982) found that females' motivation for learning Spanish was higher, although no significant gender differences were found with regard to their instrumental and integrative orientations. However, Ludwig (1983) found that males had more instrumental motivation in learning Spanish, German, and French. Thus, it can be assumed that instructional practices might be influenced by gender differences in motivation for L2 learning. 
Given the above issues, quite little research has focused on the relationship between motivation and L2 speaking skill. Thus, the present study embarked on narrowing down the investigation to the relationship between intrinsic/extrinsic type of motivation and L2 speaking skill in Iranian EFL learners in high schools. This study is significant since little attention has been paid to aura-oral skills of listening and speaking in Iran. However, with the widespread use of new communication technologies, both EFL teachers and students have begun to pay attention to the L2 speaking skill. Therefore, studies investigating various variables in relation to the speaking skill seem to be of great contribution. Moreover, there are various reasons why women and men try to learn a foreign language (Semmar, 2006), and there are different variables at work for male and female students with diverse interest in English speaking skills. Thus, the present study sought to address the following questions:

1. Is there any significant relationship between intrinsic/extrinsic type of motivation and attainment of L2 speaking skill among male and female Iranian EFL learners?

2. Is there any significant difference between male and female Iranian EFL learners in intrinsic and extrinsic type of motivation?

\section{METHODOLOGY}

\section{Participants}

The participants were 249 male and female students from ten state high schools in Isfahan province in central Iran. Their age ranged from 16 to 17 and they were selected based on accessibility sampling. Five boys' and five girls' high schools were chosen because of the researchers' permission and access to the schools. They were eleventh graders majoring in math, science, or humanities. They studied English as a foreign language three hours a week as part of their weekly schooling program. All participants spoke Persian as their first language.

\section{Instruments}

To assess the students' degree of intrinsic and extrinsic motivation, Wang's (2017) questionnaire was used. This questionnaire had been originally developed by Tsao and Wang (2014), but it was modified for the purpose of determining motivation relating to communication in English. In the modified version, there were seven items related to intrinsic motivation, and eight items were related to extrinsic motivation. This questionnaire has satisfactory degrees of reliability and validity 
(Wang, 2017). She declared that the convergence validity coefficients for intrinsic motivation and extrinsic motivation were 0.46 and 0.35 , respectively, and the discriminant validity coefficients were .68 and .59 , respectively. Meanwhile, the reliability of this questionnaire, as measured through Cronbach alpha in the present study, was satisfactory (0.76).

The items in the motivation questionnaire were presented on a 5 -point Likert scale, ranging from 1 (strongly disagree) to 5 (strongly agree). The possible scores of the participants' intrinsic motivation could range from 7 to 35 and those of their extrinsic motivation extrinsic motivation could range from 8 to 40 (see Wang, 2017).

The IELTS (International English Language Testing System) speaking test was used to assess the participants' speaking performance. The test consisted of an interview lasting 11-14 minutes. The validity and reliability of the speaking test was checked in the new context by obtaining expert judgment about the suitability of the test for the intended purpose from 2 experienced IELTS instructors. The participants' speaking skill was scored by the scale developed by IELTS experts. The students' speaking skill was marked against a number of criteria, including 'fluency and coherence', 'lexical resource', 'pronunciation', 'grammatical range' and 'accuracy'. Each individual's score on the test was finally represented in the form of a single 1-9 composite score. Meanwhile, their speaking skills were assessed by 2 raters. The interrater consistency, calculated using Spearman correlation, was high $(0.83, p<.001)$. Intrarater consistency estimates were calculated by having the two raters assess the students' performance after a considerable lapse of time.

Qualitative data were also gathered from semi-structured interviews with a random sample of 25 participants $(10 \%)$ for triangulation purposes. The interviews included several open-ended and yes/no questions such as "Do you think developing an advanced level of speaking ability in English is important? If so, why?", "In what ways do you think a high level of speaking in English can affect your life?", “Are you satisfied with your level of speaking ability?", and "Why do you want to improve it?"

\section{Procedures}

Before carrying out the main study in the high schools, the questionnaire was piloted on 20 participants, who were similar to the main participants in terms of age, academic level and mother tongue, to check the suitability of words, instructions, and scoring procedure. The results confirmed the desirability of the tests. Then, the 
data were collected by administering the motivation questionnaire in March 2018. The purpose of the study was explained so that the students could complete the survey more accurately. The questionnaire took approximately 30 minutes to fill in during a regular class period.

Then, the participants were contacted personally and a time was set up to administer the speaking skill test as described above in three separate parts. In the first part, the participants and the researcher introduced themselves. Then, the participants answered general questions on familiar topics (e.g., work, study, home town, etc.) for a time period of 4 to 5 minutes. In the second part, the participants were given a task card with prompts and asked to talk on a particular topic (e.g., describing a time when you helped someone). The participants had one minute to prepare and they could make notes if they wished to before speaking for 1-2 minutes. In the third part, the assessor and the participants became engaged in a discussion of more abstract issues (e.g., Why should neighbors help each other?), which were thematically linked to the topic in the second part. The discussion lasted 4-5 minutes. The first two parts were considered as monologues, and the third part was treated as a dialogic task. Finally, to explore the relationship between the participants' intrinsic/extrinsic motivation and their speaking skill scores, statistical analyses were carried out with SPSS software. Also, the interviews were recorded and the recordings were then transcribed for triangulation.

\section{RESULTS}

\section{Quantitative Results}

Table 1 displays the descriptive statistics of male and female high school students' scores on the intrinsic/extrinsic motivation as well as their speaking skill.

Table 1. Descriptive Statistics of the Male and Female Students' Intrinsic/Extrinsic Motivation and Their Speaking Scores

\begin{tabular}{|c|c|c|c|c|c|c|}
\hline & Variable & $\mathrm{N}$ & Min & Max & $M$ & $S D$ \\
\hline \multirow{3}{*}{$\frac{0}{\frac{0}{\pi}}$} & Intrinsic Motivation & 126 & 17.00 & 34.00 & 23.5 & 5.37 \\
\hline & Extrinsic Motivation & 126 & 20.00 & 39.00 & 26.8 & 5.38 \\
\hline & Speaking & 126 & 3.00 & 7.00 & 4.72 & .88 \\
\hline \multirow{3}{*}{ 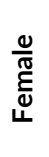 } & Intrinsic Motivation & 123 & 16.00 & 35.00 & 25.6 & 4.37 \\
\hline & Extrinsic Motivation & 123 & 13.00 & 28.00 & 21.6 & 4.34 \\
\hline & Speaking & 123 & 3.00 & 6.50 & 4.31 & 1.05 \\
\hline
\end{tabular}


To answer the first question of the study, Pearson correlation coefficients were calculated to identify the possible relations between male and female students' motivation types and their speaking ability scores. $P$ value from Pearson was obtained
Table 2. Correlations between the Male and Female Students' Intrinsic/Extrinsic Motivation and Their Speaking Skill

\begin{tabular}{ccccc}
\hline $\begin{array}{c}\text { Varia- } \\
\text { bles }\end{array}$ & \multicolumn{2}{c}{ Male } & \multicolumn{2}{c}{ Female } \\
\hline & Intrinsic & Extrinsic & Intrinsic & Extrinsic \\
\hline \multirow{3}{*}{ Speaking } & .344 & $.470^{*}$ & $.566^{*}$ & .328 \\
& $(.086)$ & $(.012)$ & $(.005)$ & $(.127)$
\end{tabular}

to determine the significance of correlation coefficient at 0.05 level.

As displayed in Table 2, the correlation coefficients indicated positive relationships between the male and female students' speaking skill and their intrinsic/extrinsic motivation. The correlation between the male students' speaking skill and and their extrinsic motivation was moderate, but statistically significant $(r=$ $0.47, p<0.05)$ with a medium effect size $\left(r^{2}=.22\right)$. Also, the correlation between the female students' speaking skill and their intrinsic motivation was statistically siginficant $(r=0.56, p<0.05)$ with a medium effect size $\left(r^{2}=.26\right)$. However, the relationship between the male students' speaking skill and their intrinsic motivation, and the female students' speaking skill and their intrinsic motivation was weak.

To answer the second research question; that is, to see whether there would be any significant difference between male and female Iranian EFL learners in intrinsic and extrinsic type of motivation, an independent sample $t$-test was performed on the intrinsic/extrinsic motivation scores of male and female EFL students. The results are reported in Tables 3 and 4.

Table 3. Independent Samples t-Test on Extrinsic Motivation Scores Between the Males and Females

\begin{tabular}{|c|c|c|c|c|c|c|}
\hline & & \multicolumn{2}{|c|}{$\begin{array}{c}\text { Levene's Test for Equality } \\
\text { of Variances }\end{array}$} & \multicolumn{3}{|c|}{$t$-test for Equality of Means } \\
\hline & & $F$ & Sig. & $t$ & $d f$ & Sig. \\
\hline \multirow{2}{*}{ 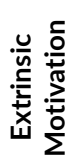 } & $\begin{array}{l}\text { Equal variances } \\
\text { assumed }\end{array}$ & .58 & .450 & 3.65 & 247 & .001 \\
\hline & $\begin{array}{l}\text { Equal variances } \\
\text { not assumed }\end{array}$ & & & 3.70 & 246.6 & .001 \\
\hline
\end{tabular}

As demonstrated in Table 3, the $t$-test results revealed a significant difference between the mean score of the male students' extrinsic motivation $(M=26.8, S D$ $=5.38)$ and the female students' extrinsic motivation $(M=21.6, S D=4.34)$. However, the eta squared statistic (.051) indicated a small effect size. 
Table 4. Independent Samples t-Test on Intrinsic Motivation Scores Between the Males and Females

\begin{tabular}{|c|c|c|c|c|c|c|}
\hline & & \multicolumn{2}{|c|}{$\begin{array}{c}\text { Levene's Test for Equality } \\
\text { of Variances }\end{array}$} & \multicolumn{3}{|c|}{$t$-test for Equality of Means } \\
\hline & & $F$ & Sig. & $t$ & $d f$ & Sig. \\
\hline \multirow{2}{*}{ 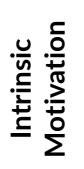 } & $\begin{array}{l}\text { Equal variances } \\
\text { assumed }\end{array}$ & 3.04 & .080 & -1.49 & 247 & .141 \\
\hline & $\begin{array}{l}\text { Equal variances } \\
\text { not assumed }\end{array}$ & & & -1.51 & 246.7 & .136 \\
\hline
\end{tabular}

As demonstrated in Table 4, there is no statistically significant difference in the mean scores of intrinsic motivation for the males and females at $.05(t=-1.49$, $p=.141)$. With the equal variances assumed across the two groups, the $t$-test results revealed that the difference between the mean score of the male students' intrinsic motivations $(M=23.5, S D=5.37)$ and the female students' intrinsic motivation $(M=25.6, S D=4.37)$ was not statistically significant. Similarly, the eta squared statistic (.004) indicated an insignificant effect size.

\section{Qualitative Results}

Interview data were also collected from a sample of 25 EFL participants to provide further insight into the quantitative results and explain some factors in relation to the EFL students' speaking skill and their extrinsic/intrinsic motivation. The analysis of the interview data from these male and female EFL students seemed to echo mostly what the quantitative results suggested in terms of the students' motivation type in relation to their speaking skill. Analysis of the data generated three major themes of having a good job, making progress in education, and enjoying English and conversations in explaining their motivation.

Having a good job. The male interviewees with high speaking skills seemed to be more extrinsically motivated. About $56 \%$ of the participants said that getting a good job in the future was so important to them and they should learn English as an international language and speak it well for job demands. However, only $24 \%$ of the female participants stated that they would like to learn English for the purpose of work requirements or job expectations. For instance, when asked to explain why they thought speaking English was important and in what ways they thought speaking good English could affect their lives, Mohsen, a high school male who was satisfied with his speaking ability, said, "If I become an engineer in a factory, for example, I am expected to deal with catalogs, which are mostly in English". Thus, he believed that good speaking skills can help him a lot in the 
future. Another male student (Mohammad) explained, "If I learn to speak well in English, I can get a well-paid job”. In fact, he had an external reason for developing his speaking skill.

Making progress in education. Another theme was related to advancement in academic settings. About $52 \%$ of the participants said that their academic advancement and success in education was related to the ability to speak well in English. A male EFL student, who wanted to continue his studies in other countries, stated, "I would like to pursue my studies abroad. I've heard from many... for us to be admitted to a good university in the west, it is necessary to get a high IELTS score. Speaking skill is a part of the test, so..., I have to work on it". He wanted to improve his speaking skill to score high on the IELTS test, which was like an award for him. Unlike the male interviewees, almost all the female ones did not claim that a high level of speaking skill could significantly affect their progress and academic careers in the future. For instance, a female student (Zahra) said, "an advanced level of speaking ability in English is important to me, I like it ... but it cannot help me make much progress in my life. I have other goals". In fact, she loved English and wanted to further develop her speaking skill because she liked speaking English.

Enjoying English and conversations. About $60 \%$ of the female students in the interviews considered speaking as an important skill and joyful activity. They enjoyed it for its own sake or because of their inherent desire for communication skills. One of the female students (Sepideh), who was a good speaker, said "I enjoy speaking English like a native speaker of English. In fact, I feel delighted when I can impress others with my ability to speak English beautifully". Another female student (Parnia), who had a high rating of speaking skill and was happy with her speaking ability, commented, "I like to learn the language and culture of the American people because it is cool. Speaking like a native speaker is the ability that not everybody can have. I enjoy speaking like an American". She asserted that, "conversation is good and speaking English is so beautiful". However, the male students generally did not point to any inherent desire of developing this skill in their interviews. Only one male student (Hamid) described his speaking skill development as a purposeful activity related to his subject area of interest. In sum, the female participants reported more powerful intrinsic motives such as joy and satisfaction related to higher level of speaking performance. 


\section{DISCUSSION}

The findings of this study revealed that the female L2 students who were intrinsically motivated were better in L2 (English) speaking skill in high schools while the male EFL students who were extrinsically motivated had a higher level of English speaking skill. In other words, the female EFL students' intrinsic motivation correlated moderately with their level of L2 speaking skill while the male L2 students' extrinsic motivation correlated, to some extent, with their level of L2 speaking skill. Although the effect sizes and degree of correlation was not very strong, especially with regard to the male students, the above results are significant and find some justifications. Males generally embark on learning activities that will be advantageous to them for pursuing their education or getting a job while, for females, internal satisfaction may be a main impetus for learning. The qualitative analysis of the interview data supported the quantitative results as well. For example, the majority of male EFL students in the interviews reported that getting good jobs and making progress in higher education, which are instances of extrinsic motivation, were the reasons why they endeavored to develop their speaking skills whereas the female students in their interviews cited internal joy, satisfaction and happinessinstances of intrinsic forms of motivation-as their main reasons for developing better speaking skill.

Based on the above findings, both types of intrinsic and extrinsic motivation can correlate with a high level of speaking skill. These findings somehow gain support from the findings of Logan, Medford, and Hughes (2011), Noels et al. (2001) and Polat, (2007), who found that intrinsic motivation correlated with language achievement. Also, Paige (2011) and Wang (2008) showed that extrinsic motivation could serve to develop language achievement. However, based on the quantitative and qualitative results, it is likely to make a distinction between the male and female EFL learners as to how they can employ their extrinsic/intrinsic motivation to develop their speaking skill better. In partial contrast to the results of the study by Semmar (2006) who reported higher ratings of both extrinsic and intrinsic motivational orientations for females, the results of descriptive statistics indicated that the male EFL students had higher extrinsic motivation. Also, the $t$-test results revealed that the difference between the mean scores of the female and male participants on the extrinsic motivation was significant even though the effect size was not large. It can be argued that higher level of extrinsic motivation among the male participants and its higher relationship to the speaking skill is related to the genderrelated differences in the context of Iran. Perhaps, as Fairclough (2001) points out, 
superior attainment in an L2 skill by a gender group can be generalizable only to that particular speech community. More likely, young males in Iran are more concerned about profession-related issues and they are more under pressure to find a good job in the future and make progress in their professional careers due to their social identity and culturally perceived roles as breadwinners in the society. In a similar vein, the qualitative data analysis from the interviews revealed that the male EFL students' motives for improving speaking ability in L2 came from external sources such as getting an IELTS certificate, getting a good job, avoiding profession-related problems in the future. It is, therefore, very likely that perceived gender-related differences in the society might affect the perceptions and motives of the students studying English in the educational context of high schools in Iran.

\section{CONCLUSION AND IMPLICATIONS}

The present study investigated the relationships between intrinsic/extrinsic motivation in each gender group and the attainment of L2 speaking skill among a sample of Iranian EFL learners. The findings indicate that there is a noticeable difference between the motivation type of male and female students for attaining a high level of speaking skill. The results show that the female EFL students with higher intrinsic motivation had better L2 speaking skill. However, the male EFL students with higher extrinsic motivation were better in L2 speaking performance. In other words, though the degree of correlation between the two types of motivation and L2 speaking skill was medium and the difference between the male and female students reached statistical significance just on the extrinsic motivation, taken together, the quantitative and qualitative results suggest that as the level of intrinsic motivation increased in the female EFL students, L2 speaking rating increased to some extent. However, for male EFL students, a similar positive association was observed between L2 speaking rating and extrinsic motivation. The higher level of extrinsic motives among the male participants in high schools might be due to socially and culturally gender-related issues represented in the context of Iran. They mostly wanted to develop their speaking skill to receive an extrinsic reward expected from them, such as a good job, or avoid punishment, such as losing a job in the future.

The above results imply that extrinsic motivation is as important as intrinsic motivation in L2 context and should not be ignored in such contexts. Unfortunately, extrinsic motivation has traditionally been considered as something that can lessen the effectiveness of L2 skill development (Dörnyei \& Ushioda, 2011). However, as the above results suggest, male students who are extrinsically motivated 
may make more effort for L2 speaking skill development. There may be a range of extrinsically motivational drives for L2 students, such as academic success in the fields of study or professional success in the future. It is, however, possible that female students benefit more from other types of motives, such as intrinsic drives in L2 skill development. They may make more effort for L2 skill development when they enjoy doing an L2-related activity or feel happy as they get close to a foreign target culture. The above findings suggest the L2 program developers and educators should pay attention to such motivational differences between male and female students in recommending and implementing instructional practices in the classroom. Also, L2 teachers should be aware of their male and female students' extrinsic or intrinsic orientations and strengthen their corresponding motives in various ways to improve their L2 oral skills.

\section{REFERENCES}

Baker, S. C., \& MacIntyre, P. D. (2000). The role of gender and immersion in communication and second language orientations. Language Learning, 50(2), 311-341. https://doi.org/10.1111/0023-8333.00224

Brown, H. D. (2014). Principles of language learning and teaching $\left(6^{\text {th }}\right.$ Ed.). White Plains, New York: Pearson.

Busse, K. (2013). Geek hierarchies, boundary policing, and the gendering of the good fan. Participations: Journal of Audience and Reception Studies, 10(1), 73-91.

Cheng, H. F., \& Dörnyei, Z. (2007). The use of motivational strategies in language instruction: The case of EFL Teaching in Taiwan. Innovation in Language Learning and Teaching, 1(1), 153-174. https://doi.org/10.2167/illt048.0

Deci, E. L. (1975). Intrinsic motivation. New York: Plenum Press.

Deci, E., Olafsen, A., \& Ryan, R. (2017). Self-determination theory in work organizations: The state of a science. Annual Review of Organizational Psychology and Organizational Behavior, 4, 19-43. https://doi.org/10.1146/annurev-orgpsych-032516-113108

Dörnyei, Z. (1998). Motivation in second and foreign language learning. Language Teaching, 31(3), 117-135. https://doi.org/10.1017/s026144480001315x

Dörnyei, Z. (2003). Attitudes, Orientations, and motivations in language learning. Oxford: Blackwell Publishing.

Dörnyei, Z. (2005). The psychology of the language learner: Individual differences in second language acquisition. Marwah: Lawrence Erlbaum Associates.

Dörnyei, Z. (2010). Researching motivation: From integrativeness to the ideal L2 self. In S. Hunston \& D. Oakey (Eds.), Introducing applied linguistics: Concepts and skills (pp. 74-83). London: Routledge.

Dörnyei, Z., \& Ushioda, E. (2011). Teaching and researching motivation. Harlow: Pearson Education Limited.

Ehrlich, S. (1997). Gender as a social practice: Implications for second language acquisition. Studies in Second Language Acquisition, 19(4), 421-446. https://doi.org/10.1017/S0272263197004014 
Ehrman, M. E, Leaver, B. L., \& Oxford, R. L. (2003). A brief overview of individual differences in second language learning. Systems, 31(3), 313-330. https://doi.org/10.1016/s0346$\underline{251 \times(03) 00045-9}$

Fairclough, N. (2001). Language and power ( $2^{\text {nd }}$ ed.). London: Longman.

Fukuchi, N. T., \& Sakamoto, R. (2005). Affective dimensions of the Japanese foreign language learner: Implications for psychological learner development in Japan. Journal of Multilingual and Multicultural Development, 26(4), 333-350. https://doi.org/10.1080/01434630508669086

Gardner, R. C. (1985). Social psychology and second language learning: The role of attitudes and motivation. London: Edward Arnold.

Gardner, R. C. (1988). The socio-educational model of second language learning: Assumptions, findings, and issues. Language Learning, 38(1), 101-126. https://doi.org/10.1111/j.14671770.1988.tb00403.x

Gardner, R. C., Tremblay, P. F., \& Masgoret, A. (1997). Towards a full model of second language learning: An empirical investigation. The Modern Language Journal, 81(3), 344362. https://doi.org/10.1111/j.1540-4781.1997.tb05495.x

Geddes, A. J. (2016). Korean university students' attitudes and motivation towards studying English. Universal Journal of Educational Research, 4(4), 704-715. https://doi.org/10.13189/ujer.2016.040407

Goldberg, M. A., \& Wolfe, D. (1982). Attitudes and motivations in American students of Spanish. The Canadian Modern Language Review, 37, 262-281. https://doi.org/10.3138/cmlr.38.2.262

Jegede, J. O. (1994). Influence of motivation and gender on secondary school students' academic performance in Nigeria. Journal of Social Psychology, 134(5), 695-697. https://doi.org/10.1080/00224545.1994.9923000

Kang, D. H. (2000). Motivation and foreign language learning in Korean EFL context. ERIC Document Reproduction Service No. ED442284.

Khorshidi, H., \& Nimchahi, A. (2013). Motivation and interlanguage pragmatics in Iranian English language learners. English Language Teaching, 6(6), 86-96. https://doi.org/10.5539/elt.v6n6p86

Kissau, S. (2006). Gender differences in motivation to learn French. Canadian Foreign Language Review, 62(3), 401-422. https://doi.org/10.3138/cmlr.62.3.401

Logan, S., Medford, E., \& Hughes, N. (2011). The importance of intrinsic motivation for high and low ability readers' reading comprehension performance. Learning and Individual Differences, 21(1), 124-128. https://doi.org/10.1016/j.lindif.2010.09.011

Ludwig, J. (1983). Attitudes and expectations: A profile of female and male students of college French, German and Spanish. Modern Language Journal, 67(3), 216-227. https://doi.org/10.1111/j.1540-4781.1983.tb01499.x

Narayanan, R., Nair, R., \& Iyyappan, S. (2007). Do female students have higher motivation than male students in learning of English at the tertiary level? Retrieved from http://eric.ed.gov/?id=ED496970

Noels, K.A., Clément, R., \& Pelletier, L.G. (2001). Intrinsic, extrinsic, and integrative orientations of French Canadian learners of English. The Canadian Modern Language Review, 57(3), 424-442. https://doi.org/10.3138/cmlr.57.3.424

Noels, K. A., Pelletier, L. G., Clément, R., \& Vallerand, R. J. (2000). Why are you learning a second language? Motivational orientations and self-determination theory. Language Learning, 50, 57-85. https://doi.org/10.1111/1467-9922.53223 
Norton, B., \& Pavlenko, A. (2004). Addressing gender in the ESL/EFL classroom. TESOL Quarterly, 38(3), 504-514. https://doi.org/10.2307/3588351

Norton, B., \& Toohey, K. (2004). Critical pedagogies and language learning. Cambridge: Cambridge University Press.

Ortega, L. (2009). Understanding second language acquisition. London: Arnold Hodder Education

Paige, D. D. (2011). Engaging struggling adolescent readers through situational interest: A model proposing the relationships among extrinsic motivation, oral reading proficiency, comprehension, and academic achievement. Reading Psychology, 32(5), 395-425. https://doi.org/10.1080/02702711.2010.495633

Polat, N. (2007). Socio-psychological factors in the attainment of L2 native-like accent of Kurdish origin young people learning Turkish in Turkey. [PhD thesis, University of Texas, Austin]. https://repositories.lib.utexas.edu/bitstream/handle/2152/3145/polatd86012.pdf?s

Ryan, R., \& Deci, E. (2000). Self-determination theory and the facilitation of intrinsic motivation, social development, and well-being. American Psychologist, 55(1), 68-78. https://doi.org/10.1037/0003-066x.55.1.68

Saville-Troike, M. (2006). Introducing second language acquisition. New York: Cambridge University Press.

Semmar, Y. (2006). An exploratory study of motivational variables in a foreign language learning context. Journal of Language and Learning, 5, 118-132.

Schumann, J. H. (1976). Second language acquisition: The pidginization hypothesis. Language Learning, 26(2), 391-408. https://doi.org/10.1111/j.1467-1770.1976.tb00283.x

Tsao, C. T., \& Wang, C. (2014). EFL students' language learning styles, learning climate, and their affective variables. Studies in English Language and Literature, 33, 79-123.

Wang, F. (2008). Motivation and English achievement: An exploratory and confirmatory factor analysis of a new measurement for Chinese students of English learning. North American Journal of Psychology, 10(3), 633-646.

Wang, C., (2017). Two affective variables and language learners' perceptions of classroom interaction. The Journal of Asia TEFL, 14(1), 16-31. http://dx.doi.org/10.18823/asiatefl.2017.14.1.2.16

Williams, M., Burden, R., \& Lanvers, U. (2002). 'French is the language of love and stuff': Student perceptions of issues related to motivation in learning a foreign language. British Educational Research Journal, 28(4), 503-528. https://doi.org/10.1080/0141192022000005805

Xie, K., \& Ke, F. (2011). The role of students' motivation in peer-moderated asynchronous online discussions. British Journal of Educational Technology, 42(6), 916-930. https://doi.org/10.1111/j.1467-8535.2010.01140.x 


\section{GHOLAMREZA SALEHPOUR}

$\mathrm{PhD}$ student of TEFL at Shahrekord University. He has been teaching English for about 20 years. His area of interest includes educational psychology.

Salehpour.ghr@gmail.com

\section{ALI ROOHANI}

Associate professor of applied linguistics. He is currently a faculty member at Shahrekord University. His area of interest includes educational psychology, language testing, and textbook evaluation. He has published 5 books and 72 papers and presented a number of papers in the national and international conferences.

roohani.ali@gmail.com

Salehpour, G., \& Roohani, A. (2020). Relationship Between Intrinsic/Extrinsic Motivation and L2 Speaking Skill Among Iranian Male and Female EFL Learners. Bellaterra Journal of Teaching \& Learning Language \& Literature, 13(1), 43-59. https://doi.org/10.5565/rev/jtl3.803

Rebut / Recibido / Received / Reçu: 10-07-2019

Acceptat / Aceptado / Accepted / Accepté: 19-12-2019

https://revistes.uab.cat/jt13/ 